\title{
The influence of rumen volatile fatty acids on protein metabolism in growing lambs
}

\author{
BY H. A. ABDUL-RAZZAQ AND R. BICKERSTAFFE* \\ Biochemistry Department, Lincoln College, Canterbury, New Zealand
}

(Received 29 July 1988 - Accepted 2 December 1988)

\begin{abstract}
The effect of acetic or propionic acid rumen fermentation patterns on whole-body protein turnover, tissue protein synthetic rates and body composition was investigated in growing lambs. Protein turnover was assessed using a continuous intravenous infusion of $\left[2,3-{ }^{3} \mathrm{H}\right]$ tyrosine and tissue protein fractional synthetic rates (FSR) from the specific activities of plasma free, intracellular free and tissue bound tyrosine. Only the FSR of muscle tissue approached significance. The high FSR in the propionic group was attributed to the high plasma insulin concentration. Values for whole-body protein synthesis, corrected for tyrosine oxidation, were similar to those obtained by summating protein synthesis in individual tissues, confirming that tyrosine oxidation should be measured accurately if reliable wholebody protein synthesis values are required. Tyrosine oxidation and flux were high in the acetic acid group, suggesting that amino acids are used for gluconeogenesis. The high protein turnover rate probably ensures an adequate supply of gluconeogenic amino acids and that the penalty of mobilizing body proteins for gluconeogenic amino acids is minimal. In the propionic acid group, high plasma glucose and insulin concentrations were associated with a low protein turnover rate, high ratio of deposited: synthesized protein and a high body fat content. It is concluded that changing the proportion of ruminal volatile fatty acids influences protein turnover, protein synthesis and the efficiency of protein retention. Such factors probably contribute, indirectly, to the observed differences in body composition.
\end{abstract}

Protein metabolism: Rumen VFA : Volatile fatty acids: Lamb

In non-ruminants, extensive studies have been made on protein turnover, but the same information is not available for ruminants. Some studies have shown that protein turnover falls as sheep age (Soltesz et al. 1973; Buttery et al. 1975, 1977; Arnal et al. 1976; Arnal, 1977; Combe et al. 1979), but only a few studies have examined the effects of dietary changes (Davis et al. 1981; Chambers \& Bickerstaffe, 1982), the physiological status of the animal (Bryant \& Smith, 1982b) or hormonal changes (Sinnet-Smith et al. 1983) on protein turnover.

Because of the extensive rumen fermentation, dietary components are converted to volatile fatty acids (VFA) such as acetic, propionic and butyric acids (Blaxter, 1961). There are, however, no reports on the effects of manipulating the proportion of rumen VFA on protein metabolism, although it has been observed that a propionic acid type of fermentation is associated with an improvement in growth efficiency (Knox \& Ward, 1961; Poole \& Allen, 1970), and that the administration of glucose or propionate to sheep improves nitrogen retention (Eskeland et al. 1974). Abdul-Razzaq (1985) also demonstrated that the concentrations of plasma glucose and insulin, both of which affect protein turnover and protein synthesis, increased with a propionic acid type of rumen fermentation.

Such circumstantial evidence suggests that a propionic acid type of fermentation should improve growth and the efficiency of energy utilization for protein synthesis. The objective of the present work was to investigate whether manipulating the proportion of rumen VFA 
does influence protein turnover or individual tissue protein synthetic rates and, through this, the growth or carcass composition of growing lambs.

\section{MATERIALS AND METHODS}

\section{Animals and feeding}

Twenty-eight lambs (Dorset Down $\delta \times$ Border-Corriedale $q$ ) weaned onto lucerne (Medicago sativa) at 6-8 weeks of age were selected at $12-14$ weeks weighing $19-21 \mathrm{~kg}$. Four animals were randomly selected and killed at the start of the experiment to determine the initial body composition. The remaining lambs were divided into two groups of twelve and fed on diets of the same composition, but processed differently.

The diets consisted of $(\mathrm{g} / \mathrm{kg}) 850$ barley, 70 lucerne meal, 60 fish meal, 10 molasses, 10 minerals and vitamins. In one diet, the barley was unprocessed and the rest of the ingredients mixed and pelleted through a $1.6 \mathrm{~mm}$ mesh. In the other, the barley was finely ground, mixed with the other ingredients and $20 \mathrm{~g} / \mathrm{kg}$ of the total mix replaced by a mineral premix consisting of $(\mathrm{g} / \mathrm{kg}) 350$ disodium hydrogen phosphate, 450 sodium bicarbonate, 150 calcium carbonate, 50 potassium chloride. The complete mixture was pelleted through a $9.5 \mathrm{~mm}$ mesh. Both diets contained $(\mathrm{g} / \mathrm{kg}) 870$ dry matter (DM), 180 crude protein $(\mathrm{N} \times 6.25 ; \mathrm{CP})$ and $18 \mathrm{MJ}$ gross energy $/ \mathrm{kg} \mathrm{DM}$, and were offered at $75 \mathrm{~g} / \mathrm{kg}$ body-weight $(\mathrm{W})^{0.75}$ per $\mathrm{d}$ in twelve equal portions using continuous feeders.

\section{Experimental procedure}

The experimental diets were given to the two groups of lambs for 10 weeks. At the end of the experimental period, the lambs were killed and the chemical composition of the body determined. Before slaughter, four animals per group were selected and continuously infused with radioactive tyrosine to determine the rates of protein turnover and protein synthesis in selected tissues.

The radioactive infusion solution contained $\mathrm{L}$-[ side-chain $\left.2,3-{ }^{3} \mathrm{H}\right]$ tyrosine $\left(21.5 \times 10^{5}\right.$ disintegrations/min (dpm) per $\mathrm{ml}$ saline $(9 \mathrm{~g}$ sodium chloride/1), batch no. 25 ; Amersham International plc, Amersham, Bucks) and was infused at $20 \mathrm{ml} / \mathrm{h}$ for $6-7 \mathrm{~h}$ into jugularvein catheters. Blood samples $(10 \mathrm{ml})$ were collected at $0 \cdot 0,0 \cdot 5,1 \cdot 0,1 \cdot 5,2 \cdot 0,3 \cdot 0,4 \cdot 0,4 \cdot 5,5 \cdot 0$, $5.5,6.0,6.5$ and $7 \cdot 0 \mathrm{~h}$ after starting the infusion, immediately centrifuged ( $1000 \mathrm{~g}$ for $15 \mathrm{~min}$ at $5^{\circ}$, and the plasma removed and stored at $-20^{\circ}$ until analysed.

Before terminating the infusion, the animals were anaesthetized with sodium pentobarbitone (Nembutal; Abbott Laboratories, Australia) and samples (10-15 g) of skeletal muscle and overlaying skin removed from the supraspinatus, longissimus dorsi and vastus lateralis muscles. After terminating the infusion, the lambs were immediately killed by exsanguination, blood collected and the body cavity opened to collect samples of heart, liver, rumen, abomasum, proximal small intestine (PSI), kidney and brain. Tissue sampling times, relative to the start of the infusion, were recorded. All tissues were collected within 5 min of slaughter, snap-frozen in liquid $\mathrm{N}_{2}$ and stored at $-20^{\circ}$ until analysed. Failure to snap-freeze within $5 \mathrm{~min}$ resulted in the specific radioactivity of intracellular tyrosine falling: a factor which affects the protein fractional synthetic rates of the tissues.

\section{Analytical methods}

Tissue-bound and intracellular tyrosine. Frozen tissue (5 g) was cut into small pieces into a preweighed $50 \mathrm{ml}$ centrifuge tube containing $3.0 \mathrm{ml}$ frozen $3 \mathrm{M}$-perchloric acid. Ice-cold water $(12 \mathrm{ml})$ was added and the tissue homogenized for $1 \mathrm{~min}$ using a Polytron homogenizer (Kinematica $\mathrm{GmbH}$, Lucerne, Switzerland). The probe was washed with $5.0 \mathrm{ml} 0.3 \mathrm{M}-\mathrm{HClO}_{4}$, the washings combined with the original homogenate and centrifuged 
for $10 \mathrm{~min}$ at $3000 \mathrm{~g}$. After removal of the supernatant fraction, the precipitated protein (tissue-bound tyrosine) fraction was washed and re-centrifuged twice with $10 \mathrm{ml} 0.3 \mathrm{M}$ $\mathrm{HClO}_{4}$. The washings plus original supernatant fraction constituted the intracellular tyrosine fraction.

The intracellular tyrosine was neutralized with 5 m-potassium hydroxide, precipitated potassium perchlorate removed by centrifuging for $10 \mathrm{~min}$ at $1000 \mathrm{~g}$ and the supernatant fraction freeze-dried. The residue was resuspended in $10 \mathrm{ml}$ water and portions removed for the determination of the concentration and radioactivity of intracellular tyrosine.

Tissue-bound tyrosine in the $\mathrm{HClO}_{4}$ precipitate was treated by a procedure described by Nicholas et al. (1977), with a few modifications. Briefly, the precipitate was washed with $20 \mathrm{ml}$ cold trichloroacetic acid $(100 \mathrm{~g} / \mathrm{l})$, followed by cold potassium acetate $(10 \mathrm{~g} / \mathrm{l}$ $94 \%$ ethanol), then warm chloroform-methanol-diethyl ether $(1: 2: 2$, by vol.) and finally diethyl ether. A portion $(100 \mathrm{mg}$ ) of the dried protein precipitate was hydrolysed in $25 \mathrm{ml}$ de-aerated $6 \mathrm{M}$-hydrochloric acid at $110^{\circ}$ for $18 \mathrm{~h}$. The contents were dried by rotary evaporation, re-dissolved in water, neutralized with $2 \mathrm{M}-\mathrm{KOH}$, and the volume adjusted to $10 \mathrm{ml}$. Portions were subsequently removed for the determination of the concentration of tissue bound tyrosine.

Concentration and specific radioactivity of tyrosine. The concentrations of plasma free tyrosine, intracellular tyrosine, tissue bound tyrosine and tyramine were determined by the fluorimetric method of Waalkes \& Udenfriend (1957); the coefficient of variation was $5 \%$ (n 65). Tyrosine specific radioactivity was determined by decarboxylating tyrosine to tyramine with L-tyrosine decarboxylase (EC 4.1.1.25), as described by Garlick \& Marshall (1972), except tyramine was selectively extracted into 3-methyl-1-butanol followed by 0.2 $\mathrm{M}-\mathrm{HCl}$ rather than ethyl acetate and sulphuric acid; the coefficient of variation was $8 \%$ ( $n$ 43). The method, which is specific, eliminates any possible contamination from radioactive D-tyrosine or any other non-tyrosine substance. All radioactivity measurements were made using scintillation-counting techniques and a Philips PW 4700 liquid-scintillation counter; the counting efficiency was $86-94 \%$ for ${ }^{14} \mathrm{C}$ and $27-38 \%$ for ${ }^{3} \mathrm{H}$ using the external standard channels ratio.

Specific radioactivity of plasma water. Tyrosine oxidation was determined by measuring the appearance of tritium in plasma water. Specific activity $(\mathrm{nCi} / \mathrm{ml})$ of plasma water was measured by transferring $1 \mathrm{ml}$ plasma to a $10 \mathrm{ml} \mathrm{RB}$ flask connected to a gas-transfer unit with a vacuum tap and tapered test-tube. The plasma was frozen, the unit vacuumed and the test-tube submerged in liquid $\mathrm{N}_{2}$. Water was collected in the test-tube by vacuum sublimation. A portion of the water was subsequently transferred to a scintillation vial, the volume made up to $1.0 \mathrm{ml}$ and radioactivity determined after the addition of $15 \mathrm{ml}$ $0.4 \%$ PPO in Triton $\times 100$-toluene $(1: 2, \mathrm{v} / \mathrm{v})$.

\section{Calculations}

Tryrosine flux. The specific radioactivity of plasma tyrosine was plotted against the sampling times for each animal, and the rise to plateau specific activity fitted to a single exponential function using the OPTIMISE function of GENSTAT 5. The fitted equation was:

$$
S p=S p \max \left(1-e^{-\lambda p t}\right),
$$

where $S p(\mathrm{nCi} / \mu \mathrm{g})$ is the plasma tyrosine specific activity at any time, $S p$ max the plateau specific activity, $\lambda p(\mathrm{~h})$ the rate-constant and $t(\mathrm{~h})$ the sample time (Shipley \& Clark, 1972). Tyrosine flux or turnover $(\mathrm{mg} / \mathrm{min})$ was calculated by the equation:

$$
\text { flux }=\frac{\text { infusion rate }(\mathrm{nCi} / \mathrm{min})}{S p \max (\mathrm{nCi} / \mu \mathrm{g}) \times 1000} .
$$


Tissue protein fractional synthetic rate $(F S R)$. FSR $\left(K_{s}\right)$ is the percentage of the total protein synthesized/d and was calculated by the formula described by Garlick et al. (1973):

$$
\frac{S b}{S i}=\frac{\lambda_{i}}{\lambda_{i}-K_{s}} \frac{1-e^{-K_{s} t}}{1-e^{-\lambda_{i} t}} \frac{K_{s}}{\lambda_{i}-K_{s}}
$$

where $S b$ and $S i$ are the specific activities $(\mathrm{nCi} / \mu \mathrm{g})$ of protein bound and free tyrosine, $\lambda_{i}$ (/d) the rate-constant for the rise to plateau of the tissue tyrosine specific activity, $t$ (d) the time of sampling and $K_{s}(\% / \mathrm{d})$ the FSR. For slow-turning-over tissues (e.g. muscle) $\lambda_{i}$ was not determined but was approximated by $R K_{s}$, as described by Garlick et al. (1973), where $R$ is the concentration ratio, bound:free tyrosine in the tissue. FSR was calculated by the formula:

$$
\frac{S b}{S i}=\frac{R}{R-1} \frac{1-e^{-K_{s} t}}{1-e^{-R \cdot K_{s} t}} \frac{1}{R-1} .
$$

In fast-turning-over tissues such as liver and small intestine, $\lambda_{i}$ was approximated by $\lambda p$. The FSR in these tissues was calculated from the formula:

$$
\frac{S b}{S i}=\frac{\lambda p}{\lambda p-K_{s}} \frac{1-e^{-K_{s} t}}{1-e^{-\lambda p t}} \frac{K_{s}}{\lambda p-K_{s}} .
$$

In all the calculations described, the intracellular free tyrosine pool was assumed to be the amino acid precursor pool from which tRNA is charged for protein synthesis. The calculated FSR represents the maximum FSR (Davis et al. 1981).

Whole-body protein synthesis (WBPS). WBPS $(\mathrm{g} / \mathrm{d})$ was calculated by two methods. In the first method protein synthesized in individual tissues was calculated from the formula: $K_{s}(\% / \mathrm{d}) \times$ tissue protein $(\%) \times$ tissue weight $(\mathrm{g})$ and WBPS by summating protein synthesized in the individual tissues.

In the second method, WBPS was calculated by substituting the flux of tyrosine and the tyrosine content of body protein $(3.25 \%$ in the present study) into the formula:

$$
\text { WBPS }(\mathrm{g} / \mathrm{d})=\text { flux }(\mathrm{mg} / \mathrm{min}) \times 1.44 \times 30.8 ;
$$

1.44 converts flux to $\mathrm{g} / \mathrm{d}$ and 30.8 , flux to protein.

Whole-body FSR (WBFSR). WBFSR was calculated from the formula:

$$
\text { WBFSR }(\% / d)=\frac{\text { WBPS }(g / d)}{\text { total body protein }(g)} \times 100 .
$$

Tyrosine oxidation. The specific radioactivity of plasma water was plotted against the plasma sampling times. In all the animals, linear regression lines were obtained $(r>0.93)$ after $2 \mathrm{~h}$ indicating that the accumulation of ${ }^{3} \mathrm{H}_{2} \mathrm{O}$ occurred at a constant rate. The proportion of tyrosine oxidized or catabolized was calculated as:

Oxidation rate $(\% / \mathrm{min})$

$$
=\frac{\text { rate of }{ }^{3} \mathrm{H} \text { incorporation into plasma water }(\mathrm{nCi} / \mathrm{min}) \times \text { body water }(\mathrm{ml})}{\left[{ }^{3} \mathrm{H}\right] \text { tyrosine infusion rate }(\mathrm{nCi} / \mathrm{min})} \times 100 \text {. }
$$

Body water was determined from chemical analysis of the carcass and non-carcass components isolated from the animals by methods previously described (Abdul-Razzaq et al. 1988). Losses of ${ }^{3} \mathrm{H}$ in breath and urine during the infusion period were not estimated. Similar assumptions were made by Fuller et al. (1987). 


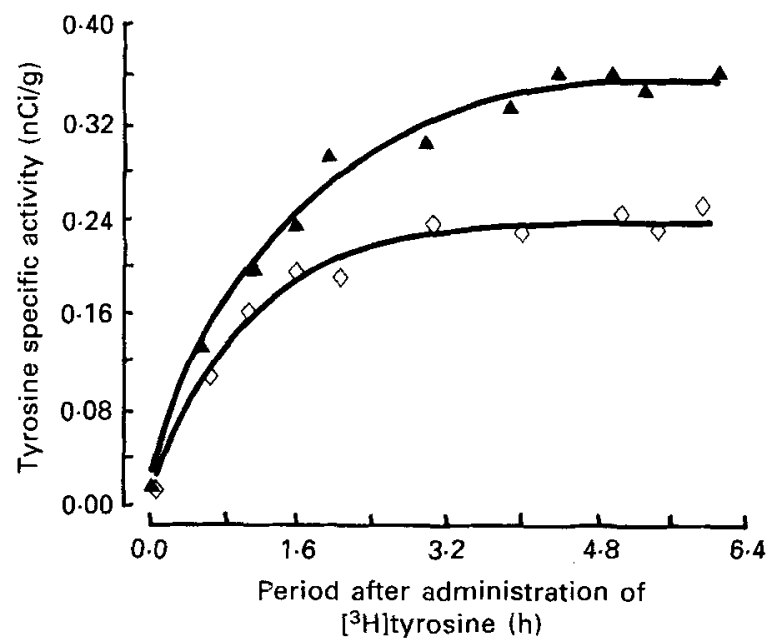

Fig. 1. Time-course of the appearance of radioactivity in plasma free tyrosine on infusing L-[side chain $\left.2,3 \cdot{ }^{3} \mathrm{H}\right]$ tyrosine $(17 \cdot 1 \mathrm{kBq} / \mathrm{min})$ into growing lambs with acetic $(\diamond-\diamond)$ or propionic $(\boldsymbol{\Delta}-\boldsymbol{\Delta})$ fermentation patterns. For details of dietary regimens, see p. 298.

\section{RESULTS}

The effect of feeding whole loose barley or ground barley on the proportion of rumen VFA and the body composition of growing lambs has been previously reported (Abdul-Razzaq et al. 1988). Giving whole loose barley produced a propionic acid type of fermentation (total VFA $5 \cdot 28$ (SE 0-19) g/l, individual VFA ( $\%$ of total) acetate $43 \cdot 1$ (SE $1 \cdot 1$ ), propionate 38.9 (SE $2 \cdot 1$ ), butyrate 11.5 (SE $1 \cdot 0$ ), valerate 2.3 (SE $0 \cdot 3$ )). Pelleted ground barley produced an acetic acid type of fermentation (total VFA 4.90 (SE 0.38$) \mathrm{g} / 1$, individual VFA (\% of total) acetate 47.4 (SE 1.8), propionate 20.2 (SE 0.9), $P<0.001$; butyrate 20.1 (SE 1.0), $P<0.001$; valerate 6.8 (SE 0.9 ), $P<0.01$ ). The two groups of lambs, with the propionic and acetic acid types of fermentation, were characterized by acetic:propionic acid ratios of $1 \cdot 13$ (SE 0.08) and 2.37 (SE 0.5) $(P<0.001)$ respectively and were designated the $\mathrm{Pr}$ and A groups.

\section{Intravenous infusion of $L$-[side chain $\left.2,3-{ }^{3} H\right]$ tyrosine}

Four animals from each group were intravenously infused with $\left[2,3-{ }^{3} \mathrm{H}\right]$ tyrosine for $7 \mathrm{~h}$. Fig. 1 shows the typical results from one of the animals. The specific activity of plasma tyrosine gradually increased and reached a stable plateau specific activity. Such results, together with the small fluctuations in plasma tyrosine concentrations (Table 1) showed that the animals were in steady-state. The time-period for the specific activity of plasma tyrosine to reach $95 \%$ of the final plateau value was faster in the A group than in the Pr group (Table 1) and approached statistical significance $(P<0 \cdot 1)$. The flux of tyrosine was also higher in the A group than in the Pr group but, due to the within-group animal variations, the difference was not statistically significant $(P>0 \cdot 1)$.

At the end of the infusion period, the animals were killed and the specific activities of intracellular free $(S i)$ and bound tyrosine $(S b)$ in selected tissues determined. The specific activity of intracellular free tyrosine $(S i)$ was $18-60 \%$ of the plasma specific activity $(S p)$ as shown by the $S i: S p$ values in Table 2 . In both groups the small intestine, liver and kidney had the lowest $S i: S p$ ratios and muscle, heart and rumen, the highest. There was a tendency 
Table 1. Concentration of plasma free tyrosine, tyrosine flux and the time-period to reach a plateau in growing lambs with acetic or propionic rumen fermentation patterns $\dagger$

(Mean values with their standard errors)

\begin{tabular}{|c|c|c|c|c|}
\hline & \multicolumn{4}{|c|}{ Type of fermentation } \\
\hline & \multicolumn{2}{|c|}{ Acetic } & \multicolumn{2}{|c|}{ Propionic } \\
\hline & Mean & $\mathrm{SE}$ & Mean & $\mathrm{SE}$ \\
\hline Plasma tyrosine concentration $(\mathrm{mg} / \mathrm{ml})_{\ddagger}^{+}$ & $7 \cdot 26$ & 0.74 & $7 \cdot 75$ & $0 \cdot 78$ \\
\hline Time-period $(\mathrm{h})$ to reach plateau specific activity & $2 \cdot 90$ & $0 \cdot 25$ & $3 \cdot 70^{*}$ & $0 \cdot 30$ \\
\hline Tyrosine flux $(\mathrm{mg} / \mathrm{min}) \S$ & $11 \cdot 8$ & 0.76 & $10 \cdot 1$ & 0.95 \\
\hline
\end{tabular}

Mean value was different from that for acetic acid fermentation (Student's $t$ test): ${ }^{*} P<0 \cdot 1$.

$\dagger$ For details of dietary regimens, see p. 298.

\#ach value is the mean of twelve samples obtained from four animals on each diet.

$\S$ Each value is the mean for four animals.

Table 2. Intracellular free tyrosine specific activity: plasma tyrosine specific activity ratio in the body tissues of growing lambs with acetic or propionic rumen fermentation patternst

(Mean values with their standard errors, for four animals per group)

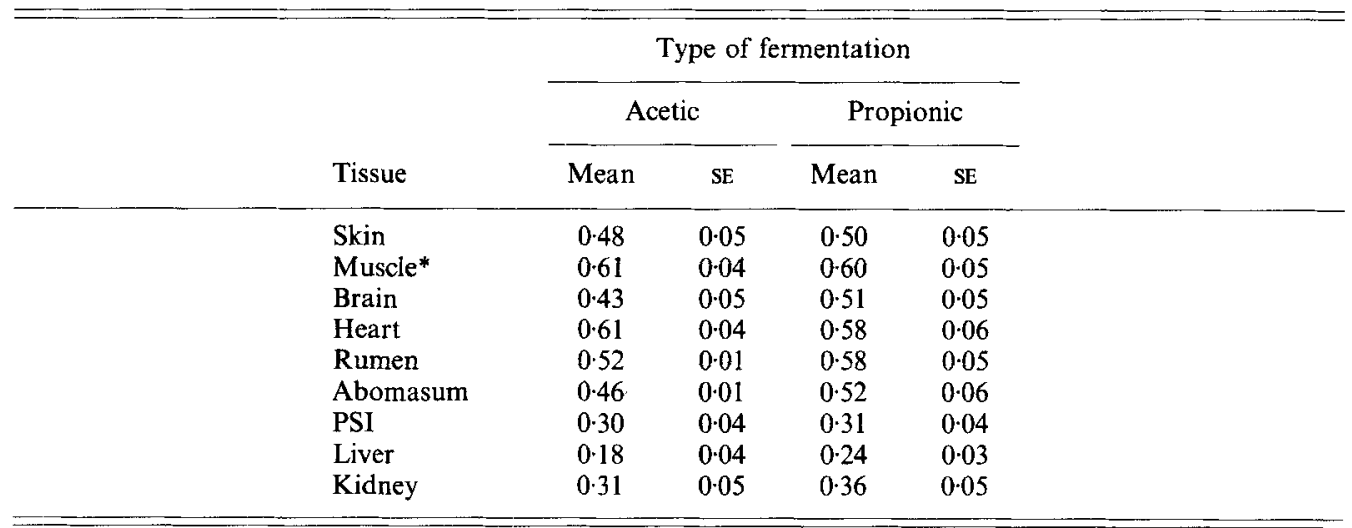

PSI, proximal small intestine.

* Mean value from the supraspinatus, longissimus dorsi and vastus lateralis.

$\uparrow$ For details of dietary regimens, see p. 298.

for the ratios to be higher in the Pr group than in the A group, but the differences were not statistically significant. $S i$ is lower than $S p$ due to the catabolism of intracellular protein and the release of amino acids. Indeed, Table 3 shows that the intracellular free tyrosine concentrations (IFTC) are two to ten times higher than the concentrations of plasma free tyrosine (PFTC). The IFTC:PFTC value varies between the tissues, but there is a tendency for the ratios to be higher in the Pr group. This is attributed to changes in IFTC rather than in PFTC. 
Table 3. Concentrations ( $\mu \mathrm{g} / \mathrm{g}$ tissue) of intracellular free tyrosine (IFTC) and the ratio of IFTC: plasma free tyrosine concentrations (PFTC) in tissues of growing lambs with acetic or propionic rumen fermentation patterns $\uparrow$

(Mean values with their standard errors, for four animals per group)

\begin{tabular}{|c|c|c|c|c|c|c|c|c|}
\hline & \multicolumn{4}{|c|}{ IFTC $(\mu \mathrm{g} / \mathrm{g}$ tissue $)$} & \multicolumn{4}{|c|}{ IFTC:PFTC } \\
\hline & \multicolumn{4}{|c|}{ Type of fermentation } & \multicolumn{4}{|c|}{ Type of fermentation } \\
\hline & \multicolumn{2}{|c|}{ Acetic } & \multicolumn{2}{|c|}{ Propionic } & \multicolumn{2}{|c|}{ Acetic } & \multicolumn{2}{|c|}{ Propionic } \\
\hline & Mean & SE & Mean & SE & Mean & $\mathrm{SE}$ & Mean & $\mathrm{SE}$ \\
\hline Skin & $42 \cdot 9$ & $1 \cdot 6$ & $34 \cdot 4$ & $4 \cdot 6$ & $6 \cdot 1$ & 0.72 & $4 \cdot 4^{*}$ & 0.14 \\
\hline Muscle & $19 \cdot 4$ & $1 \cdot 0$ & $22 \cdot 5^{*}$ & $1 \cdot 4$ & $2 \cdot 7$ & 0.06 & $2 \cdot 9^{*}$ & 0.03 \\
\hline Brain & $17 \cdot 1$ & $1 \cdot 5$ & $22 \cdot 1^{*}$ & $1 \cdot 7$ & $2 \cdot 6$ & 0.42 & $2 \cdot 9$ & $0 \cdot 25$ \\
\hline Heart & $20 \cdot 8$ & $2 \cdot 7$ & $23 \cdot 7$ & $1 \cdot 4$ & $2 \cdot 9$ & $0 \cdot 10$ & $3 \cdot 2$ & $0 \cdot 30$ \\
\hline Rumen & $25 \cdot 1$ & $3 \cdot 0$ & $26 \cdot 0$ & $1 \cdot 6$ & $3 \cdot 5$ & $0 \cdot 38$ & $3 \cdot 5$ & 0.36 \\
\hline Abomasum & $38 \cdot 4$ & $3 \cdot 1$ & $42 \cdot 3$ & $3 \cdot 0$ & $5 \cdot 5$ & 1.00 & 5.7 & 0.74 \\
\hline PSI & $50 \cdot 3$ & $4 \cdot 9$ & $73 \cdot 3 * *$ & $7 \cdot 1$ & $7 \cdot 1$ & $1 \cdot 00$ & $9 \cdot 9$ & 1.80 \\
\hline Liver & 19.8 & 1.9 & $28 \cdot 1$ & 3.7 & $2 \cdot 8$ & 0.05 & 3.8 & 0.76 \\
\hline Kidney & $47 \cdot 2$ & $4 \cdot 3$ & $82 \cdot 8^{*}$ & $12 \cdot 0$ & 6.7 & $0 \cdot 76$ & $11 \cdot 2$ & $2 \cdot 20$ \\
\hline
\end{tabular}

PSI, proximal small intestine.

Mean values were different from those for acetic acid fermentation (Student's $t$ test): ${ }^{*} P<0 \cdot 1,{ }^{*} P<0 \cdot 05$.

$\dagger$ For details of dietary regimens, see p. 298.

+ Mean value from the supraspinatus, longissimus dorsi and vastus lateralis.

\section{Tissue protein FSR}

$S i$ and $S b$ were used to calculate the maximum protein FSR in the different tissues from both groups of lambs (Table 4). The results show that skeletal muscle had the lowest FSR and the small intestine the highest FSR. In the fast-turning-over tissues, there were large variations in FSR, and in the slow-turning-over tissues, small variations. In most tissues the FSR tended to be higher in the Pr group than in the A group, except for liver and kidney where the values were higher in the A group (Table 4). Differences between the two groups were not statistically significant, except for muscle which approached significance $(P<0 \cdot 1)$. The FSR of the supraspinatus, longissimus dorsi and vastus lateralis muscles were examined individually, but there were no significant differences between the muscles within or between treatments.

\section{WBPS}

The maximum amount ( $\mathrm{g}$ ) of protein synthesized per $\mathrm{d}$ in each individual tissue is summarized in Table 5. Although skeletal muscle had the highest protein content, the amount of protein synthesized was lower than that observed in the skin or digestive tract. This is attributed to the low FSR of skeletal muscle. There were no significant differences in tissue protein synthetic rates in the two groups, except for kidney tissue. WPBS, calculated by summating protein synthesized in individual tissues, was higher in the A group than in the Pr group (Table 5). WBPS can be calculated directly from tyrosine flux, but such a method overestimates WBPS (506 (SE 33), 479 (SE 36) g/d; A and Pr groups respectively), since it assumes that all the tyrosine is used for protein synthesis. Table 6 shows that WBPS calculated from tyrosine flux corrected for tyrosine oxidation is similar to WBPS from summating protein synthesized in individual tissues. 
Table 4. Protein fractional synthetic rates ( $F S R \dagger ; \% / d$ ) in tissues from growing lambs with acetic or propionic rumen fermentation patterns

(Mean values with their standard errors for four animals per group)

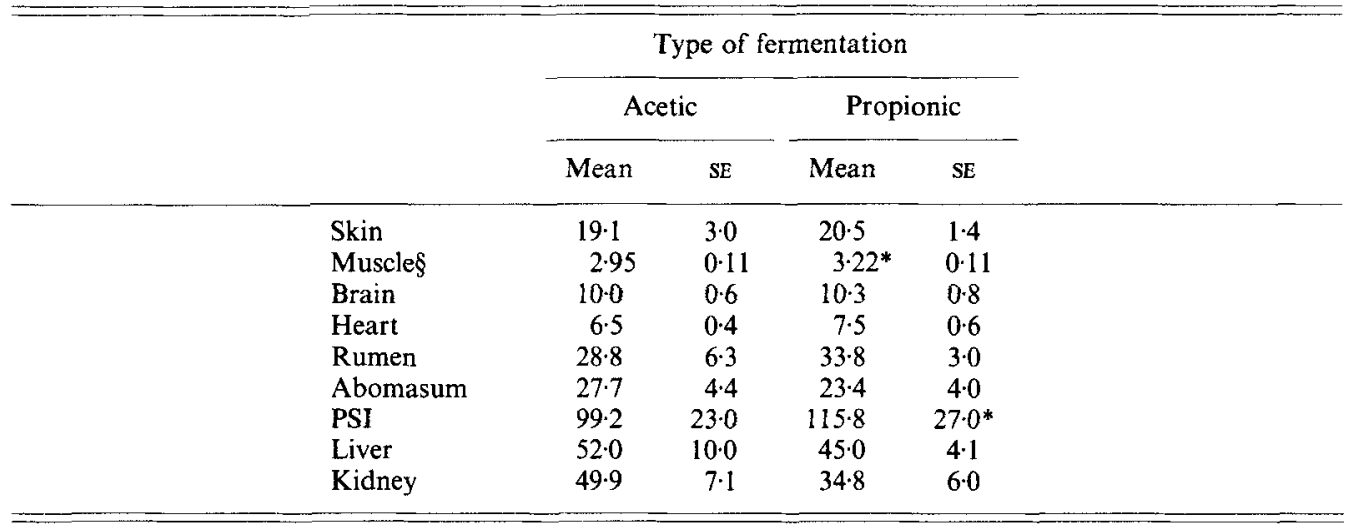

PSI, proximal small intestine.

Mean value was different from that for acetic acid fermentation (Student's $t$ test): ${ }^{*} P<0 \cdot 1$.

$\dagger$ Calculated using the intracellular pool as the precursor amino acid pool.

$\$$ For details of dietary regimens, see p. 298.

$\S$ Mean value from the supraspinatus, longissimus dorsi and vastus lateralis.

Table 5. Protein synthesis rate ( $\mathrm{g} / \mathrm{d}$ ) in tissues from growing lambs with acetic or propionic rumen fermentation patterns $\dagger$

(Mean values with their standard errors for four animals per group)

\begin{tabular}{|c|c|c|c|c|}
\hline & \multicolumn{4}{|c|}{ Type of fermentation } \\
\hline & \multicolumn{2}{|c|}{ Acetic } & \multicolumn{2}{|c|}{ Propionic } \\
\hline & Mean & SE & Mean & SE $\ddagger$ \\
\hline Skin & 107 & $17 \cdot 0$ & 103 & $9 \cdot 0$ \\
\hline Muscle $\ddagger$ & 72 & 1.5 & 77 & $3 \cdot 3$ \\
\hline Brain & 1.01 & 0.07 & 0.97 & 0.06 \\
\hline Heart & $1 \cdot 84$ & $0 \cdot 14$ & $2 \cdot 06$ & 0.26 \\
\hline Digestive tract & 93.5 & 24 & $94 \cdot 7$ & 8 \\
\hline Liver & $91 \cdot 8$ & 19 & $63 \cdot 7$ & 5.4 \\
\hline Kidneys & 8.9 & $1 \cdot 3$ & $5 \cdot 7^{*}$ & $1 \cdot 1$ \\
\hline WPBS§ & 376 & 52 & 347 & 18 \\
\hline
\end{tabular}

WBPS, whole-body protein synthesis.

Mean value was different from that for acetic acid fermentation (Student's $t$ test): ${ }^{*} P<0 \cdot 1$

$\dagger$ For details of dietary regimens, see p. 298.

$\$$ Mean value from the supraspinatus, longissimus dorsi and vastus lateralis.

$\S$ Calculated by summating protein synthesis in individual tissues using the intracellular amino pool and assuming carcass protein represents muscle protein. 
Table 6. Oxidation of tyrosine and whole-body protein synthesis (WBPS) in growing lambs with acetic or propionic rumen fermentation patterns $\dagger$

(Mean values with their standard errors for four animals per group)

\begin{tabular}{|c|c|c|c|c|}
\hline & \multicolumn{4}{|c|}{ Type of fermentation } \\
\hline & \multicolumn{2}{|c|}{ Acetic } & \multicolumn{2}{|c|}{ Propionic } \\
\hline & Mean & SE & Mean & $\mathrm{SE}$ \\
\hline Oxidation of tyrosine $(\%)$ & $19 \cdot 6$ & 1.8 & $14 \cdot 2^{*}$ & $0 \cdot 3$ \\
\hline WBPS $\ddagger(g / d)$ & 400 & 18 & 399 & 32 \\
\hline
\end{tabular}

Mean value was different from that for the acetic acid fermentation (Student's $t$ test): ${ }^{*} P<0 \cdot 1$.

$\uparrow$ For details of dietary regimens, see p. 298.

\$ Calculated from tyrosine flux corrected for tyrosine oxidation.

Table 7. Total protein, protein gain, protein synthesis and the fractional rates of protein synthesis (FSR), body gain (FGR) and breakdown rates (FBR) in the body of growing lambs with acetic or propionic rumen fermentation patterns*

(Mean values with their standard errors for four animals per group)

\begin{tabular}{|c|c|c|c|c|}
\hline & \multicolumn{4}{|c|}{ Type of fermentation } \\
\hline & \multicolumn{2}{|c|}{ Acetic } & \multicolumn{2}{|c|}{ Propionic } \\
\hline & Mean & SE & Mean & $\mathrm{SE}$ \\
\hline Body protein $(\mathrm{g})$ & 4700 & 110 & 4920 & 70 \\
\hline Body protein gain $(\mathrm{g} / \mathrm{d}) \dagger$ & 23.95 & 1.44 & 26.68 & $1 \cdot 14$ \\
\hline Body protein synthesis $(\mathrm{g} / \mathrm{d}) \ddagger$ & 376 & 52 & 347 & 18 \\
\hline Body FSR $(\% / d)$ & 8.08 & $1 \cdot 35$ & $7 \cdot 13$ & 0.3 \\
\hline Body FGR $(\% / d) \S$ & 0.50 & $0 \cdot 35$ & 0.53 & 0.04 \\
\hline Body FBR $(\% / d)$ & 7.58 & 1.37 & $6 \cdot 61$ & 0.27 \\
\hline
\end{tabular}

* For details of dietary regimens, see p. 298.

$\dagger$ Calculated from the average weight gains over the last 2 weeks of the experimental period and by assuming body composition remained constaint over this period.

$\$$ Calculated from summation of protein synthesis in individual tissue using the intracellular amino acid pool.

$\S$ Average gain over 2 weeks prior to the infusion day.

\section{Whole-body protein degradation}

FSR, fractional growth rate (FGR) and fractional degradation rate (FDR) of body protein were calculated by assuming that the average weight gain of the animals over the 2 weeks before an experimental day were representative of the weight gains on the experimental day, and that the body composition of the animals remained constant over the 2-week period (Table 7). The assumptions are probably valid since the animals maintained their feed intakes throughout the experimental infusion periods. Protein gain was calculated from live-weight changes (Oddy et al. 1987). Although the content of body protein and WBPS were higher in the Pr group than in the A group, the FSR $(\% / d)$ was lower in the Pr group. FRG (g protein gain/d per total body protein $\times 100$ ) was also higher in the Pr group than in the A group, but the FDR (FSR minus FGR) was lower. 


\section{DISCUSSION}

It should be emphasized that when discussing the effects of rumen VFA on protein metabolism it is most likely to be a discussion on the influence of the rumen VFA on the precursors or hormones that regulate protein synthesis rather than the action of rumen fatty acids per se on protein synthesis. The following discussion will therefore examine the inter-relationship between the proportion of rumen VFA, plasma glucose concentrations, plasma insulin concentrations and the rate of protein synthesis in various tissues.

\section{Protein synthesis}

The time-period required for the specific activity of plasma tyrosine to reach $95 \%$ of the plateau value was shorter in the A group (2.9 (SE 0.25) h) than in the Pr group (3.7 (SE 0.3) h) of lambs. The difference between the two groups was probably due to the higher flux rate of tyrosine in the A group (11.8 (SE 0.76$) \mathrm{mg} / \mathrm{min}$ ) than in the Pr group (10.1 (SE 0.95) $\mathrm{mg} / \mathrm{min}$ ), since the time-period to reach a plateau is dependent on the amino acid turnover rate and pool size (Waterlow et al. 1978). The time-periods to reach a plateau in the two groups were similar to those previously reported for sheep ( $2.5 \mathrm{~h}$, Bryant \& Smith, $1982 a, b$; Chambers, 1984) and cattle (3.0 h, Lobley et al. 1980).

\section{Skeletal muscle}

The FSR $\left(K_{s}, \% / \mathrm{d}\right)$ of muscle protein were similar to the values previously reported for growing lambs (Davis et al. 1981 ; Chambers \& Bickerstaffe, 1982), lower than in newborn lambs (Soltesz et al. 1973) and higher than in mature sheep (Buttery et al. 1975). Different muscles had different FSR but the results were not significantly different. Schreurs \& B ekholt (1980) also found that different myofibril proteins turned over at different rates. Cunsequently, it is recommended that in all future work muscles from different locations should be analysed and an average protein synthetic rate determined. In the present work, the supraspinatus, longissimus dorsi and vastus lateralis were selected and found to be satisfactory muscles from which to determine the average synthetic rate of muscle protein.

Plasma insulin concentrations were consistently higher in the $\mathrm{Pr}$ group than in the A group (1.5 (SE 4.79), 2.9 (SE 15.19) $\mu \mathrm{U} / \mathrm{ml}$ respectively, $P<0.05$ ), and associated with this was a higher muscle protein FSR (3.22 (SE 0.11), 2.95 (SE 0.11) \%/d for Pr and A groups respectively, $P<0 \cdot 1$ ), which supports the concept that insulin stimulates muscle protein synthesis in ruminants. Insulin is also involved in regulating protein synthesis in simplestomached animals (Jefferson et al. 1977; Stirewalt \& Low, 1983). Plasma glucose concentrations were also higher in the Pr group than in the A group (836 (SE 22) and 711 (SE 32$) \mathrm{mg} / 1$ respectively, $P<0.05$ ) so it is feasible that both glucose and insulin stimulate muscle protein synthesis. Fulks et al. (1975) observed that, in non-ruminant animals, glucose in the presence of insulin stimulated protein synthesis.

\section{Liver}

There are two difficulties in measuring liver protein synthesis; the experimental method only measures fixed liver proteins (Waterlow et al. 1978) and the liver removes C-2 from $\mathrm{L}-\left[2,3-{ }^{3} \mathrm{H}\right]$ tyrosine (Nicholas et al. 1977). Both difficulties result in liver protein synthesis being underestimated, but in the present work the results can be used for comparative purposes.

The mass $(176.5(\mathrm{SE} 9.6) v .142 .0(\mathrm{SE} 6.2) \mathrm{g}$ protein respectively; $P<0.05)$ and FSR (52 (SE 10) v. 45 (SE $4 \cdot 1) \% / d$ respectively) of liver protein were all higher in the A group than in the Pr group. The increase in liver protein mass in the A group is probably due to protein synthesis being stimulated and protein degradation being inhibited by the high 
concentration of plasma amino acids (Abdul-Razzaq et al. 1988). Alternatively, the reduction in liver mass in the Pr group would be due to the high plasma insulin concentrations, which are characteristic of the group, reducing the flow of amino acids from the peripheral tissues to the liver. Insulin has been reported to suppress the peripheral mobilization of amino acids and to inhibit liver gluconeogenesis (Bassett, 1978).

\section{Small intestine}

The FSR of intestinal epithelial tissue in the present study agrees with literature values (Waterlow et al. 1978), although Alpers \& Kinzie (1973) suggest that the availability of intestinal amino acids probably affects the rate of protein synthesis. The latter implies that the higher concentration of duodenal amino acids in the Pr group than in the A group (47.5 (SE 6.4) v. 33.4 (SE 5.3) $\mathrm{mg}$ amino acids/g wet weight respectively) may explain the higher rate of intestinal protein synthesis in the Pr group.

\section{Brain and heart}

Wallace (1948) and Fell et al. (1972) reported that sheep brain weights vary little over the first 6 months of life. It is, therefore, not surprising that the experimental treatments had no effect on protein synthesis in the brain. Similarly, the experimental treatments had no effect on the FSR of heart tissue, although insulin and glucose have been reported to stimulate protein synthesis in rat hearts (Morgan et al. 1971).

\section{WBPS and protein turnover}

Despite the high body protein content and high protein gain in the Pr group (Table 7), WBPS tended to be lower in the Pr group than in the A group (Table 5), which implies that protein degradation was higher in the A group. It is also interesting that the difference $(13.2 \%)$ in protein FDR between the two groups (Table 7) was similar to the difference $(14 \%)$ in plasma tyrosine flux (Table 1); both variables being higher in the A group. Thus, the A group animals are characterized by a high WBPS rate, a high protein degradation rate, a fast rise to plateau and a low net protein gain.

There were differences in the concentrations of duodenal amino acids in the two groups, but such amino acids have little impact on the concentration of the circulating amino acids (Berman \& Heitmann, 1980) since they are utilized by the intestinal mucosa and liver. Such facts infer that the high tyrosine flux in the $\mathbf{A}$ group is not due to differences in the absorption of tyrosine or the synthesis of tyrosine, which is minimal under normal feeding conditions (Moldawer et al. 1983), but to a high protein breakdown rate induced by a fast protein turnover rate. Such an hypothesis is supported by the work of Bryant \& Smith (1982a) who reported that tyrosine flux was $30 \%$ lower in concentrate-fed than in roughage-fed sheep, diets likely to produce propionic and acetic acid types of fermentation respectively.

Since the concentrations of plasma glucose and insulin were higher in the Pr group than in the A group (Abdul-Razzaq et al. 1988), it is probable that both glucose and insulin are responsible for the low protein turnover rate in the Pr group. Such a conclusion is supported by previous work, which has shown that the administration of glucose or propionate improved $\mathrm{N}$ retention (Eskeland et al. 1974), and that insulin stimulated protein synthesis and inhibited protein breakdown in sheep (Chrystie et al. 1977; Bassett, 1978). Thus, it is apparent that the manipulation of the pattern of rumen VFA indirectly affects protein turnover by influencing the concentration of metabolites, such as glucose or insulin, which are derived from or influenced by the end-products of rumen fermentation.

Changes in protein turnover are important to animals since turnover requires energy and such energy is wasted in terms of net protein deposition. Indeed the efficiency of protein 
deposition is affected by the energy expended on protein turnover. For example, lowering protein turnover, and hence the energy expended on protein turnover $(4.2 \mathrm{~kJ} / \mathrm{g}$ protein; Van Es, 1980), improves the energetic efficiency of an animal. This concept is supported by the low protein turnover rate (376 (SE 52) and 347 (SE 18) g/d for groups A and $\mathrm{Pr}$ respectively) and high retention of dietary energy as body energy (19.7 (SE 1.1) and 24.0 (SE $0.9) \%$ for groups A and Pr respectively; $P<0.01$ ) in the Pr group of animals. Such evidence illustrates that the Pr group was more energetically efficient than the A group. Indeed, the efficiency of protein retention as expressed by the ratio, deposited protein : synthesized protein (Reeds et al. 1980) was higher in the Pr group (1:13) than in the A group $(1: 16)$. This difference in the efficiency of protein retention is probably responsible for the higher rate of fat gain (3.01 (SE 0.23) and 4.09 (SE 0.33) kg fat/trial period for groups A and $\mathrm{Pr}$ respectively; $P<0.05$ ) and fat content (181 (SE 8) and 214 (SE 10) g/kg empty-body-weight for groups A and Pr respectively; $P<0.05$ ) in the animals consuming the same gross energy (1028 (SE 37.2) and 1054 (SE 24.7) total MJ intake for groups A and Pr respectively), but with acetic and propionic types of rumen fermentation (Abdul-Razzaq et al. 1988).

In contrast, the high concentrations of plasma amino acids and plasma urea together with the high tyrosine flux and high tyrosine oxidation rate imply that in group $A$ amino acids are used for alternative pathways, such as gluconeogenesis, in addition to the pathways synthesizing protein. Indeed, Lindsay (1979) has suggested that the utilization of amino acids for gluconeogenesis limits their availability for protein synthesis, and that a simple inverse relationship between amino acids flowing into glucose or protein should not be expected. MacRae \& Egan (1980) and Lindsay (1982) also suggested that ruminants use glucose and amino acids in an integrated system which allows the interconversion between glucose and amino acids to occur to maintain glucose homeostasis. Evidence in support of such conclusions is the ability of ruminants to convert glucose into non-essential amino acids (MacRae \& Egan, 1980; Lindsay, 1981; Wilson et al. 1983), and their capacity to adjust the utilization of glucose (Brockman, 1978). About 40-50\% of the glucose may be involved in such pathways (Leng \& Ball, 1978; Rowe et al. 1978).

If such pathways were operating in the A group of animals, then a high protein turnover rate would be beneficial, since it would facilitate a rapid interconversion between glucose and amino acids and with this a consequential economy in the utilization of glucose and amino acids. Such processes were aided by the low plasma insulin concentrations in group A.

In summary, the present study had indicated that changes in protein turnover and protein synthesis are associated with changes in the proportion of rumen VFA. It is also apparent that the rumen VFA influence protein synthesis, protein turnover and the efficiency of the utilization of dietary energy by affecting the concentration of plasma metabolites, particularly glucose and insulin. Such changes are probably responsible for the changes in the body composition of the lambs (Abdul-Razzaq et al. 1988). The proportion of individual fatty acids in the rumen also has an influence on the supply of gluconeogeneic precursors, but a mechanism is required to maintain the balance of these and other precursors so that gluconeogenesis and protein synthesis are sustained or adjusted to meet the growth requirements of the animals. Further work is required to elucidate the details of such a mechanism.

\section{REFERENCES}

Abdul-Razzaq, H. A. (1985). Influence of rumen volatile fatty acids and insulin on the metabolism of glucose and protein in lambs. PhD Thesis, Lincoln College, University of Canterbury, New Zealand.

Abdul-Razzaq, H. A., Bickerstaffe, R. \& Savage, G. P. (1988). The influence of rumen volatile fatty acids on 
blood metabolites and body composition of growing lambs. Australian Journal of Agricultural Research 39 , 505-515.

Alpers, D. H. \& Kinzie, J. L. (1973). Regulation of small intestinal protein metabolism. Gastroenterology 64, 471-496.

Arnal, M. (1977). Muscle protein turnover in lambs throughout development. In Proceedings of the 2 nd International Symposium on Protein Metabolism and Nutrition. European Association of Animal Production, Publication no. 22, pp. 35-37 [S. Tamminga, editor]. Wageningen, The Netherlands: Centre for Agricultural Publishing and Documentation.

Arnal, M., Ferrara, M. \& Fauconneau, G. (1976). Protein synthesis in vivo during the development of various muscles in lambs. In Proceedings of an International Conference on Isotopes in Agriculture, pp. 393-401. Vienna, Austria: International Atomic Energy Agency.

Bassett, J. M. (1978). Endocrine factors in the control of nutrient utilization: ruminants. Proceedings of the Nutrition Society 37, 273-280.

Bergman, E. N. \& Hejtmann, R. N. (1980). Metabolism of amino acids by the gut, liver, kidneys and peripheral tissues. In Protein Deposition in Animals, pp. 69-76. [P. J. Buttery and D. B. Lindsay, editors]. London and Boston: Butterworths.

Blaxter, K. L. (1961). Energy utilisation in the ruminants. In Digestive Physiology and Nutrition of the Ruminant, pp. 183-197 [D. Lewis, editor]. London: Butterworths.

Brockman, R. P. (1978). Roles of glucagon and insulin in the regulation of metabolism in ruminants-a review. Canadian Veterinary Journal 19, 55-62.

Bryant, D. T. W. \& Smith, R. W. (1982a). Protein synthesis in muscle of mature sheep. Journal of Agricultural Science, Cambridge 99, 319-323.

Bryant, D. T. W. \& Smith, R. W. $(1982 b)$. The effect of lactation on protein synthesis in ovine skeletal muscle. Journal of Agriculiural Science, Cambridge $\mathbf{9 8}, 639-643$.

Buttery, P. J., Beckerton, A. \& Lubbock, M. H. (1977). Rates of protein metabolism in sheep. In Proceedings of the 2nd International Symposium on Protein Metabolism and Nutrition. European Association of Animal Production, Publication no. 22, pp. 32-34. [S. Tamminga, editor]. Wageningen, The Netherlands: Centre for Agricultural Publishing and Documentation.

Buttery, P. J., Beckerton, A., Mitchell, R. M., Davies, K. \& Annison, E. F. (1975). The turnover rate of muscle and liver protein in sheep. Proceedings of the Nutrition Society 34, 91A-92A.

Chambers, J. A. N. (1984). Glucose, protein and energy metabolism in suckling and ruminating lambs. PhD Thesis, Lincoln College, The University of Canterbury, New Zealand.

Chambers, J. A. N. \& Bickerstaffe, R. (1982). Effect of rumen development on protein synthesis in lambs. Proceedings of the Nutrition Society Australia 7, 148 A.

Chrystie, W. W., Horn, J., Sloan, I., Stern, M., Noakes, D. \& Young, M. (1977). Effect of insulin on protein turnover in foetal lambs. Proceedings of the Nutrition Society 36, 118 A.

Combe, E., Attaix, D. \& Arnal, M. (1979). Protein turnover in the digestive tissues of the lamb throughout development. Annales des Recherches Vétérinaires 10, 436-439.

Davis, S. R., Barry, T. N. \& Hughson, G. A. (1981). Protein synthesis in tissues of growing lambs. British Journal of Nutrition 46, 409-419.

Eskeland, B., Pfander, W. H. \& Preston, R. L. (1974). Intravenous energy infusions in lambs: effects on nitrogen retention, plasma free amino acids and plasma urea nitrogen. British Journal of Nutrition 31, $201-211$.

Fell, B. F., Campbell, R. M., Mackie, W. S. \& Weekes, T. E. C. (1972). Changes associated with pregnancy and lactation in some extra-reproductive organs of the ewe. Journal of Agricultural Science, Cambridge 79, $397-407$.

Fulks, R. M., Li, J. B. \& Goldberg, A. L. (1975). Effects of insulin, glucose and amino acids on protein turnover in rat diaphragm. Journal of Biological Chemistry 250, 290-298.

Fuller, M. F., Reeds, P. J., Cadenhead, A., Seve, B. \& Preston, T. (1987). Effects of the amount and quality of dietary protein on nitrogen metabolism and protein turnover of pigs. British Journal of Nutrition 58, $287-300$.

Garlick, P. J. \& Marshall, I. (1972). A technique for measuring brain protein synthesis. Journal of Neurochemistry 19, 577-583.

Garlick, P. J., Millward, D. J. \& James, W. P. T. (1973). The diurnal response of muscle and liver protein synthesis in vivo in the meal-fed rats. Biochemical Journal 136, 935-945.

Jefferson, L. S., Li, J. B. \& Rannels, S. R. (1977). Regulation by insulin of amino acid release and protein turnover in the perfused rat hemicorpus. Journal of Biological Chemistry 252, 1476-1483.

Knox, K. L. \& Ward, G. M. (1961). Rumen concentrations of volatile fatty acids as affected by feeding frequency. Journal of Dairy Science 44, 1550-1553.

Leng, R. A. \& Ball, F. M. (1978). The role of glucose in growth. Proceedings of the Australian Society of Animal Production 12, $135 \mathrm{~A}$.

Lindsay, D. B. (1979). Is gluconeogenesis from amino acids important in ruminants? In Protein Metabolism in the Ruminant pp. 71-79. [P. J. Buttery, editor]. London: Agricultural Research Council.

Lindsay, D. B. (1981). Characteristics of the metabolism of carbohydrates in ruminants compared with other animals. In The Problem of Dark-cutting in Beef, pp. 101-113. [D. E. Hood and P. V. Tarrant, editors]. The Hague: Martinus Nijhoff. 
Lindsay, D. B. (1982). Relationship between amino acid catabolism and protein anabolism in the ruminant. Federation Proceedings 41, 2550-2554.

Lobley, G. E., Milne, V., Lovie, J. M., Reeds, P. J. \& Pennie, K. (1980). Whole body and tissue protein synthesis in cattle. British Journal of Nutrition 43, 491-502.

MacRae, J. C. \& Egan, A. R. (1980). The measurements of glucose kinetics in sheep: what relevance do such measurements have to the glucose requirements of an animal? In Energy Metabolism pp. 421-426. [L. E. Mount, editor]. London and Boston: Butterworths.

Moldawer, L. L., Kawamura, I., Bistrian, B. R. \& Blackburn, G. L. (1983). The contribution of phenylalanine to tyrosine metabolism in vivo. Studies in the post-absorptive and phenylalanine-loaded rat. Biochemical Journal 210, $811-817$.

Morgan, H. E., Jefferson, L. S., Wolpert, E. B. \& Rannels, D. E. (1971). Regulation of protein synthesis in heart muscle. Journal of Biological Chemistry 246, 2163-2170.

Nicholas, G. A., Lobley, G. E. \& Harris, C. I. (1977). Use of constant infusion technique for measuring rates of protein synthesis in New Zealand white rabbit. British Journal of Nutrition 38, 1-17.

Oddy, V. H., Lindsay, D. B., Barker, P. J. \& Northrop, A. J. (1987). Milk production in ewes fed high grain diets. British Journal of Nutrition 58, 437-452.

Poole, D. A. \& Allen, D. M. (1970). Utilization of salts of volatile fatty acids by growing sheep. 5. Effects of type of fermentation of the basal diet on the utilization of salts of acetic acid for body gains. British Journal of Nutrition 24, 695-704.

Reeds, P. J., Cadenhead, A., Fuller, M. F., Lobley, G. E. \& McDonald, J. D. (1980). Protein turnover in growing pigs. Effects of age and food intake. British Journal of Nutrition 43, 445-455.

Rowe, J. B., Nolan, J. V. \& Leng, R. A. (1978). Measurement of propionic acid and glucose metabolism using a modelling approach. Proceedings of the Australian Society of Animal Production 12, 136A.

Schreurs, V. V. A. M. \& Boekholt, H. A. (1980). A study of the relative turnover of muscle proteins. European Association of Animal Production 27, 538-543.

Shipley, R. A. \& Clark, R. E. (1972). Tracer Methods for in vivo Kinetics; Theory and Applications, pp. $239-246$. New York: Academic Press.

Sinnett-Smith, P. A., Dumelow, N. W. \& Buttery, P. J. (1983). Effects of trenbolone acetate and zeranol on protein metabolism in male castrate and female lambs. British Journal of Nutrition 50, 225-234.

Soltesz, G., Joyce, J. \& Young, M. (1973). Protein synthesis rate in the newborn lamb. Biology of the Neonate 23, 139-148.

Stirewalt, W. S. \& Low, R. B. (1983). Effects of insulin in vitro on protein turnover in rat epitrochlearis muscle. Biochemical Journal 210, 323-330.

Van Es, A. J. H. (1980). Nutritional efficiency of protein and fat deposition. In Protein Deposition in Animals, pp. 215-224. [P. J. Buttery and D. B. Lindsay, editors]. London and Boston: Butterworths.

Waalkes, T. P. \& Udenfriend, S. (1957). A fluroimetric method for the estimation of tyrosine in plasma and tissues. Journal of Laboratory and Clinical Medicine 50, 733-766.

Wallace, L. R. (1948). The growth of lambs before and after birth in relation to the level of nutrition. Journal of Agricultural Science, Cambridge 38, 243-302.

Waterlow, J. C., Garlick, P. J. \& Millward, D. J. (1978). Protein Turnover in Mammalian Tissues and in the Whole Body. Amsterdam: North-Holland Publishing Company.

Wilson, S., MacRae, J. C. \& Buttery, P. J. (1983). Glucose production and utilization in non-pregnant, pregnant and lactating ewes. British Journal of Nutrition 50, 303-316. 